\title{
Penerapan Prinsip Manajemen Sumber Daya Insani di Kampung Cokelat Blitar
}

\author{
Nadya Amira Husna', Nur Aini Latifah² \\ IAIN Tulungagung ${ }^{1,2}$ \\ Jl. Mayor Sujadi Timur No 46 Tulungagung1,2 \\ E-mail : nadyaamira375@gmail.com ${ }^{1}$; neng.nurainilatifah@gmail.com²
}

Diterima: 25 Mei 2018; Direvisi: 29 Juni 2018; Diterbitkan: 3 Juli 2018

\begin{abstract}
Abstrak,
Seiring dengan perkembangan zaman, kegiatan ekonomi juga mengalami perkembangan, tidak ketinggalan juga ekonomi Islam. Sebagai seorang muslim diwajibkan untuk selalu mengaplikasikan ajaran Islam dalam setiap kehidupannya, termasuk dalam aktivitas manajemen yang dijalankan. Manajemen perusahaan mencakup pengelolaan sumber daya manusia yang dapat dipadukan dengan ajaran-ajaran Islam yang bersumber dari Al-Qur'an dan Hadist. Penerapan manajemen berbasis syariah pada umumnya hanya dilakukan oleh perusahaan yang pemiliknya seorang muslim yang mengharuskan seluruh karyawannya mengikuti aturan yang telah ditetapkan secara syariah. Salah satunya yaitu perusahaan Kampung Coklat Blitar ini. Penelitian ini menggunakan metode kualitatif, dengan pengumpulan data dilakukan melalui wawancara dan observasi secara mendalam dan selama periode. Penelitian menemukan bahwa implementasi manajemen sumber daya manusia berbasis syariah di Kampung Coklat Blitar ini meliputi proses rekrutmen (persyaratannya yaitu harus beragama Islam dan berjilbab bagi perempuan), proses seleksi (harus mengikuti beberapa tes), pelatihan dan pengembangan (bersifat religius), dan penilaian kinerja (menggunakan hasil kerja dan perilaku). Hasil juga menunjukkan bahwa perusahaan Kampung Coklat Blitar ini dalam penerapan manajemen sumber daya manusia berbasis syariah sudah sesuai dengan ajaran-ajaran Islam. Dengan melaksanakan pemberian reward kepada karyawan yang berperilaku baik.
\end{abstract}

Kata Kunci: Manajemen Sumber Daya Manusia, Ekonomi Islam, Syariah

\section{Abstract,}

Along with developing era, economic activity is also developed, even islamic economic follows the development too. As muslim, it is a must to stay applying Islam lesson in daily life, it includes term of management activity that is going on. Management of company consists of management of human resouce that can be integrated with Islam lessons and sourced from Al-Qur'an and Hadist. Implementation of management based on syariah commonly is only done by the company that the owner is a muslim who obligates whole of his or her employees follows syariah regulations. One of them is this Kampung Coklat's Blitar company. This research uses qualitative methods, with data collection conducted through interviews and indepth observation and during the period. The study found that the implementation of Shariahbased human resource management in Kampung Coklat Blitar included recruitment process, the selection process (must follow some tests), training and development (religious), and performance appraisal (using work and behavior). The results also show that this Blitar Coklat Village company in the implementation of syariah based human resource management is in 
accordance with the teachings of Islam. By implementing rewards to employees who behave well.

Keywords: Human Resource Management, Islamic Economics, Syariah

\section{PENDAHULUAN}

Dalam era perdagangan bebas dunia abad 21 telah terjadi iklim kompetisi yang sangat tinggi di segala bidang yang menuntut perusahaan untuk bekerja dengan lebih efektif dan efisien. Tingkat kompetisi yang tinggi menuntut pula suatu organisasi untuk mengoptimalkan sumber daya manusia yang dimilikinya. Hal ini disebabkan karena pengaruh yang kuat dari sumber daya manusia terhadap efektivitas dan efisiensi organisasi. Organisasi merupakan sekumpulan orang yang memiliki tujuan bersama dan bekerjasama untuk mencapai tujuan tersebut. Keberlangsungan organisasi tidak lepas dari peran manajemen karena melalui manajemen yang baik dapat menghasilkan organisasi sesuai dengan harapan dan tujuan organisasi itu. Semua organisasi, baik yang berbentuk badan usaha ataupun badan yang bersifat publik, tentu mempunyai suatu tujuan sendiri-sendiri yang merupakan motivasi dari pendiriannya. ${ }^{1}$

Pentingnya manajemen sumber daya manusia telah didasari oleh semua pihak karena manajemen sumber daya manusia telah menjadi kebutuhan pokok perusahaan atau lembaga. ${ }^{2}$ Manajemen pada dasarnya dibutuhkan oleh semua organisasi karena tanpa manajemen, semua usaha ataupun kegiatan untuk mencapai suatu tujuan akan sia-sia belaka. ${ }^{3}$ Sumber daya manusia merupakan modal dan kekayaan yang terpenting dari setiap kegiatan manusia. Manusia sebagai unsur terpenting mutlak dianalisis dan dikembangkan dengan cara tersebut, waktu, tenaga dan kemampuannya benar-benar dapat dimanfaatkan secara optimal bagi kepentingan organisasi maupun bagi individu. Hubungan manajemen dengan sumber daya manusia merupakan proses usaha pencapaian tujuan melalui kerja sama dengan orang lain. Ini berarti menunjukkan pemanfaatan sumber daya manusia untuk mencapai tujuan organisasi. ${ }^{4}$ Mei Sulastri Sonya Aziziyah, menganalisis bahwa peran pemilik perusahaan terhadap proses manajemen sumber daya manusia berbasis Islam telah berjalan cukup maksismal. Dengan memberikan penghargaan nantinya akan memotivasi karyawan lainnya

\footnotetext{
${ }^{1}$ Zainul Arifin, “Dasar-Dasar Manajemen Bank Syariah”, (Jakarta: Alvabeta, 2005), hlm.97.

2 Faustino Cordoso Gomes, "Manajemen Sumber Daya Manusia", (Yogyakarta: Andi Offset, 2003), hlm.4. hlm.6.

3 Susilo Martyo, "Manajemen Sumber Daya Manusia", (Yogyakarta: BPFE-Yogyakarta, 1990),

4 Abdurrahmat Fathoni, “Organisasi dan Manajemen Sumber Daya Manusia”, (Jakarta: PT. Rineka Cipta, 2006), hlm.9.
} 
untuk dapat meningkatkan kinerjanya. ${ }^{5}$ Fadhilah Rahmatika, menganalisis bahwa secara garis besar nilai-nilai Islam tetap diperhatikan dan diterapkan dalam praktik MSDM di BNI Syariah. aspek Islami ditunjukkan dengan memasukkan beberapa kriteria-kriteria, tes, atau materi pada beberapa praktik manajemen.

Kemudian sisi spiritualitas juga dilihat dari keikutsertaan karyawan pada beberapa kegiatan religi yang diadakan, hal ini mencerminkan sisi ke-Islaman dari seseorang. ${ }^{6}$ Damingun, menganalisis bahwa perubahan pada pengetahuan dan kebiasaan merupakan hasil dari pelatihan. Reaksi atas program pelatihan berkaitan dengan karakter personal dan situasional dalam persepsi peserta perihal dukungan manajemen, isi pelatihan berkaitan dengan pekerjaan mereka serta otoritas dan kebebasan mereka untuk memulai perubahan yang disarankan dalam pelatihan.7 Muhammad Mustaqim, menganalisis bahwa pengembangan SDM Setia Kudus pada dasarnya mencerminkan prinsip-prinsip syariah. Meskipun masih banyak permasalahan yang terkait dengan pengembangan MSDM. Implementasi prinsip syariah dalam implementasi MSDM di UD Setia Kudus pada prinsipnya sudah relevan. Seperti dalam proses rekrutmen, seleksi, pengembangan SDM dan kompensasi. ${ }^{8}$ Jumaidah Hasim, menganalisis bahwa karyawan-karyawan Muslim yang bekerja di organisasi-organisasi Islam di Malaysia sadar akan praktik-praktik manajemen sumber daya manusia berbasis Islam yang sering mereka pratikkan dalam bekerja. ${ }^{9}$

Sebenarnya manajemen sumber daya manusia bukanlah sesuatu hal yang baru di lingkungan organisasi, khususnya di bidang bisnis. Usaha manusia untuk bekerjasama secara sistematik dalam arti sengaja, berencana dan terarah pada suatu tujuan yang disebut organisasi. Bersamaan dengan kecenderungan manusia untuk bekerjasama di dalam organisasi itu, telah berlangsung juga perilaku manusia untuk memanfaatkan atau mendayagunakan manusia dalam rangka mencapai suatu tujuan. Agama Islam merupakan agama yang mayoritas dipeluk oleh masyarakat Indonesia. Islam memberikan warna tersendiri bagi aspek kehidupan bagi yang memeluknya, seperti segi ibadah, sosial, politik, dan ekonomi meskipun Indonesia tidak menggunakan agama sebagai dasar Negara.

5 Mei Sulastri Sonya Aziziyah, "Praktik Penerapan Manajemen Sumber Daya Manusia Berbasis Islam pada Steak and Shake di Perusahaan Waroeng Group Timoho Yogyakarta”, Skripsi, (Yogyakarta: Fakultas Ekonomi, UIN Syarif Hidayatullah Yogyakarta, 2014).

${ }^{6}$ Fadhilah Rahmatika, "Penerapan MSDM Berbasis Nilai-Nilai Islami pada Bank BNI Syariah Semarang”, Skripsi, (Semarang: Fakultas Ekonomika dan Bisnis, UNDIP Semarang, 2014).

7 Damingun, Peran Pelatihan Sumber Daya Manusia Dalam Perspektif Islam, (STIE Muhammadiyah Samarinda, Vol.10 No.1 : Januari 2016)

8 Muhammad Mustaqim, Prinsip Syariah Dalam Manajemen Sumber Daya Manusia (studi atas implementasi manajemen sumber daya manusia UMKM di Kudus), (STAIN Kudus, Vol.10 No.2 : Agustus 2016)

9 Jumaidah Hasim, Penerapan Manajemen Islam dalam Suatu Organisasi (studi di Internasional Islamic University Malaysia), Vol.2 No.3 : 2009 
Masyarakat muslim percaya apabila keselamatan dan keberuntungan akan dicapai ketika kaum muslim menerapkan dan mengamalkan ajaran agama dalam kehidupannya. Dalam AlQur'an ditegaskan kepada setiap muslim untuk senantiasa terikat dengan aturan-aturan Allah SWT dalam setiap aspek kehidupannya. Termasuk dalam konsep manajemen, konsep ini difokuskan pada manajemen sumber daya manusia dalam proses ketenagakerjaan.

Sumber daya manusia merupakan kekuatan terbesar dalam pengelolaan seluruh sumber yang ada dimuka bumi, karena pada dasarnya seluruh ciptaan Allah SWT yang sengaja diciptakan untuk kemaslahatan umat manusia. Islam menghendaki manusia berada pada tatanan yang tinggi. Oleh karena itu, manusia dikaruniai akal, perasaan, dan tubuh yang sempurna. Kesempurnaan tersebut dimaksudkan agar manusia menjadi individu yang dapat mengembangkan diri dan menjadi anggota masyarakat yang berdaya guna sehingga dapat mengembangkan seluruh potensi sumber daya yang dimilikinya. ${ }^{10}$

Seiring dengan perkembangan zaman, kegiatan ekonomi juga mengalami perkembangan, tidak ketinggalan juga ekonomi Islam. Kegiatan ekonomi Islam memperlihatkan tanda-tanda yang cukup menggembirakan walaupun masih banyak kekurangan dan kelemahannya. Tanda-tanda tersebut adalah adanya pertumbuhan dan perkembangan organisasi atau perusahaan yang sudah menerapkan manajemen sumber daya manusia berbasis syariah di Indonesia, salah satunya yaitu Kampung Coklat Blitar ini. Kajian ini difokuskan pada implementasi manajemen sumber daya manusia berbasis syariah di Kampung Coklat Blitar, kendala yang di hadapi Kampung Coklat dalam mengimplementasikan manajemen sumber daya manusia berbasis syariah, dan solusi yang dilakukan dalam meminimalisir kendala yang dihadapi dalam mengimplementasikan manajemen sumber daya manusia berbasis syariah di Kampung Coklat Blitar.

\section{TINJAUAN TEORITIK}

\section{Konsep Manajemen}

Manajemen berarti pengelola, ketatalaksanaan. Manajemen berarti penggunaan sumber daya secara efektif untuk mencapai sasaran. ${ }^{11}$ Secara etimologis, istilah manajemen hingga sekarang tidak ada standar istilah yang disepakati oleh para ahli. Menurut Hasibun, manajemen adalah ilmu dan seni mengatur pemanfaatan sumber daya manusia dan sumbersumber lainnya secara efektif dan efisien untuk mencapai suatu tujuan tertentu. ${ }^{12}$ Manajemen hlm.308.

${ }_{10}$ Buchari Alma dan Donni Juni Priansa, “Manajemen Syariah”, (Bandung: Alfabeta, 2014),

${ }^{11}$ Depdiknas, "Kamus Bahasa Indonesia", (Jakarta: Pusat Bahasa, 2008), hlm.909-910.

12 Malayu S.P. Hasibun, “Manajemen, Dasar, Pengertian dan Masalah”, (Jakarta: PT. Gunung Agung, 1989), hlm.3. 
sebagai ilmu dimaksudkan bahwa manajemen dapat dipelajari dan menjadi salah satu cabang ilmu pengetahuan, dapat diterapkan untuk memecahkan persoalan-persoalan dalam perusahaan, sedangkan manajemen sebagai suatu seni ialah bahwa dalam mencapai tujuan yang diinginkan, seorang pimpinan sangat tergantung pada kemampuannya untuk mempengaruhi orang lain yang ada di bawahnya.

Istilah manajemen diberi banyak arti yang berbeda sesuai dengan titik berat fokus yang dianalisis. Inti dari manajemen adalah mengelola sumber daya yang ada, terutama sumber daya manusia agar melakukan kerjasama melaksanakan kegiatan untuk mencapai tujuan bersama. Pendekatan manajemen merupakan suatu keniscayaan, apalagi jika dilakukan dalam suatu organisasi atau lembaga. Dengan organisasi yang rapi, akan dicapai hasil yang lebih baik daripada yang dilakukan secara individual. Diliat dari penjelasan diatas dapat dikatakan bahwa menejemen adalah suatu kerjasama dari orang-orang atau kelompok orang untuk mencapai suatu tujuan yang telah disepakati bersama dengan cara-cara yang sistematis, efisien, dan efektif.

\section{Manajemen Sumber Daya Manusia berbasis Syariah}

Manajemen sumber daya manusia adalah penataan pegawai yang mencakup tata cara memperoleh dan menggunakan tenaga kerja dengan efisien untuk mencapai tujuan yang telah

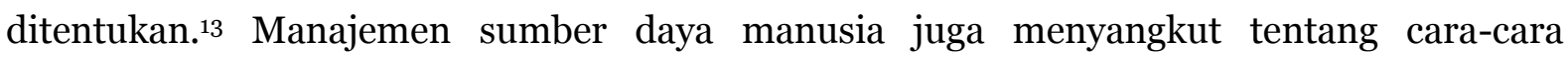
mendesain sistem perencanaan, penyusunan karyawan, dan hubungan ketenagakerjaan. Manajemen sumber daya manusia melibatkan semua praktik manajemen yang dapat memengaruhi secara langsung terhadap organisasi. Manajemen sumber daya manusia terdiri dari serangkaian kebijakan yang terintegrasi tentang hubungan ketenagakerjaan yang memengaruhi orang-orang dan organisasi.

Apabila manajemen sumber daya manusia dikaitkan dengan syariah, berarti manajemen sumber daya manusia yang dilaksanakan menggunakan pendekatan syariah, khususnya yang terkait dengan tenaga dan pegawai dalam suatu organisasi. Manajemen Sumber Daya Manusia dalam perspektif syariah diarahkan pada dua perbuatan manusia di dunia, yaitu perbuatan yang dinamakan muamalah dan perbuatan yang termasuk dalam kategori ibadah. Suatu perbuatan ibadah pada dasarnya tidak boleh dilakukan kecuali ada dalil atau ketentuan yang terdapat dalam Al-Qur'an dan Hadist yang menyatakan bahwa perbuatan itu harus atau boleh dilakukan. Sedang dalam muamalah pada dasarnya semua hlm.42.

13 E. Mulyasa, "Manajemen Berbasis Sekolah", (Bandung: PT. Remaja Rosdakarya, 2004), 
perbuatan boleh dilakukan kecuali ada ketentuan dalam Al-Qur'an dan Hadist yang melarangnya. ${ }^{14}$

Kaitannya dengan konsep manajemen sumber daya manusia berbasis syariah, manajemen sumber daya manusia berbasis syariah adalah suatu ilmu manajemen yang berisi struktur teori menyeluruh yang konsisten dan dapat dipertahankan dari segi empirisnya yang didasari pada jiwa dan prinsip-prinsip Islam. Manajemen sumber daya manusia berbasis syariah membahas struktur yang merupakan sunatullah dan struktur yang berbeda-beda itu merupakan ujian Allah SWT. Manajemen sumber daya manusia berbasis syariah membahas tentang sistem dimana sistem yang dibuat harus menyebabkan perilaku pelakunya berjalan dengan baik.

Islam telah memberikan perhatian dan pandangan yang mendalam terhadap pengembangan sumber daya manusia. Bukan hanya manusia sebagai khalifah dimuka bumi ini, namun juga kepada nilai-nilai sikap dan perilaku manusia itu sendiri. Saifuddin Bachrun menyatakan bahwa ada tiga cakupan dalam manajemen sumber daya manusia berbasis syariah yaitu pertama, penilaian kinerja tidak hanya dilakukan pada saat bekerja, namun juga dalam setiap tingkah laku selama hidup di dunia. Karena itu manusia dianjurkan berhati-hati dalam menjalani kehidupannya. Kedua, penilaian kinerja berdasarkan Al-Qur'an evaluasi penilaian kinerja ada dua metode yaitu evaluasi berdasarkan pertimbangan (kepribadian dan karakter) dan evaluasi berdasarkan perilaku. Ketiga, Islam menganjurkan pelatihan dan pengembangan tidak hanya untuk meningkatkan pengetahuan dan ketrampilan, tapi juga pengembangan moral, dan pengembangan spiritual manusia.

\section{Ruang Lingkup Manajemen Sumber Daya Manusia berbasis Syariah}

\section{Rekrutmen}

Rekrutmen atau penarikan tenaga kerja dapat diartikan sebagai suatu proses untuk menentukan dan menarik tenaga kerja baru yang cocok dengan kualifikasi dan kebutuhan perusahaan atau dengan kata lain proses menempatkan orang yang tepat di posisi yang tepat. ${ }^{15}$ Dalam memilih karyawan, Islam menyarankan agar selektif dalam memilih calon karyawan mana yang berkualitas dan merupakan orang-orang yang tepat.

Dalam pandangan Islam, proses rekrutmen harus dilakukan secara adil, terbuka, dan tanpa adanya unsur nepotisme. Keputusan dalam proses rekrutmen akan berdampak pada pelaksanaan aspek-aspek SDM lainnya seperti pelatihan dan pengembangan, penilaian kerja, dll. Islam menganjurkan dalam memilih atau merekrut karyawan dalam perusahaan atau

14 Zainul Arifin, “Dasar-Dasar Manajemen Bank Syariah”, ... .,hlm.91.

15 Burhanuddin Yusuf, "Manajemen Sumber Daya Manusia Di Lembaga Keuangan Syariah”, (Jakarta: PT. RajaGrafindo Persada, 2015), hlm.94. 
organisasi harus yang kompeten dan religius (persyaratan harus beragama Islam dan berjilbab). Persyaratan rekrutmen sebaiknya dicantumkan dengan jelas kepada pelamar, seperti syarat-syarat pekerjaan, kriteria pekerjaan. Dan sebaliknya pelamar juga memberikan keterangan yang sesuai dan tidak melamar pekerjaan di luar kemampuannya. Dalam proses rekrutmen, Islam menganjurkan agar dalam memilih atau menyeleksi karyawan yang akan diterima oleh suatu organisasi atau perusahaan seharusnya dilakukan sebaik mungkin sehingga tidak akan terjadi salah rekrut dan penempatan karyawan.

\section{Seleksi}

Seleksi berarti penyaringan, pemilihan (untuk mendapatkan yang terbaik), sedangkan menurut istilah seleksi berarti metode dan prosedur yang dipakai oleh bagian personalia (perusahaan) waktu memilih orang untuk mengisi lowongan pekerjaan. Serangkaian metode dan prosedur yang dilakukan tidak hanya untuk mengetahui kemampuan kandidat, tetapi juga untuk mengetahui kepribadian kandidat sehingga diperoleh sikap amanah. ${ }^{16}$ Proses seleksi sebagai sarana yang digunakan dalam memutus pelamar mana yang diterima. ${ }^{17}$ Seleksi pada dasarnya bertujuan untuk mendapatkan tenaga kerja yang memenuhi syarat dan memiliki kualifikasi yang sesuai dengan deskripsi pekerjaan yang ada atau sesuai dengan kebutuhan organisasi atau perusahaan. ${ }^{18}$

Bagi manajer muslim sangat perlu untuk memahami tuntunan dalam Al-Qur'an yang dapat mencegah penerimaan yang tidak jelas dan nepotisme dan untuk mencegah diskriminasi dalam tempat kerja. Dalam manajemen berbasis syariah keahlian saja tidak cukup. Jadi harus diimbangi dengan etos kerja dan tanggungjawab yang tinggi. Maka setiap muslim dalam beraktivitas apapun harus dilakukan dengan cara yang professional. Yang dimaksudkan professional menurut Islam dicirikan oleh tiga hal yaitu Ahliyah (keahlian), Himmatul 'Amal (etos kerja tinggi), dan Amanah (terpercaya dan bertanggungjawab). ${ }^{19}$

\section{Pelatihan dan Pengembangan}

Pelatihan adalah proses sistematik pengubahan perilaku para pegawai dalam suatu arah guna meningkatkan tujuan-tujuan organisasional. ${ }^{20}$ Sedangkan pengembangan adalah sebagai penyiapan individu untuk memikul tanggungjawab yang berbeda atau yang lebih

16 Depdiknas, “Kamus Bahasa Indonesia”, ... .,hlm.8oo.

17 Veithzal Rivai dan Ella Jauvani S, "Manajemen Sumber Daya Manusia untuk Perusahaan (Teori dan Praktik), Edisi kedua”, (Jakarta: Rajawali Pers, 2009), hlm.159.

${ }_{18}$ Burhanuddin Yusuf, "Manajemen Sumber Daya Manusia. . ..,hlm.115.

19 Muhammad Islamil Yusanto dan Muhammad Karebeet W, "Menggagas Bisnis Islam", (Jakarta : Gema Insani Press, 2002), hlm.104.

20 Ambar Teguh S dan Rosidah, "Manajemen Sumber Daya Manusia (Konsep, Teori dan Pengembangan dalam Konteks Organisasi Publik)", (Yogyakarta : Graha Ilmu, 2003), hlm.175. 
tinggi di dalam organisasi. Pengembangan biasanya berhubungan dengan peningkatan kemampuan intelektual atau emosional yang diperlukan untuk menunaikan pekerjaaan yang lebih baik. ${ }^{21}$ Pelatihan dan pengembangan itu penting karena keduanya merupakan cara yang digunakan oleh organisasi atau perusahaan untuk mempertahankan, menjaga dan memelihara pegawai publik dalam organisasi sekaligus meningkatkan keahlian para pegawai untuk kemudian dapat meningkatkan produktivitasnya.

Pengembangan SDM lebih terfokus ke jangka panjang. Melalui program pengembangan akan mengurangi ketergantungan organisasi terhadap adanya program pengangkatan karyawan baru, karena program pengembangan semata-mata untuk memberdayakan karyawan dalam organisasi untuk jangka panjang. Dalam hal ini organisasi atau perusahaan selalu berupaya untuk mendapatkan sumber daya manusia yang berkualitas guna menunjang efektivitas kegiatan dalam perusahaan. Upaya tersebut dapat berupa program pelatihan dan pengembangan yang di rencanakan.

Islam mendorong untuk melakukan pelatihan (training) terhadap para karyawan dengan tujuan mengembangkan kompetensi dan kemampuan dalam menjalankan tanggungjawab pekerjaannya dan pelatihan ini diutamakan bersifat Islami. Islam menegaskan bahwa pelatihan dan pengembangan mencakup mulai dari pengembangan moral, spiritual, dan pada akhirnya dimuat pada kebijakan fiskal. Pelatihan dan pengembangan harusnya mengantarkan pada peningkatan keimanan kepada Allah SWT dan untuk menambah pengetahuan dan ketrampilan pekerja.

Islam tidak hanya mendorong seseorang untuk bekerja, tetapi juga memotivasi untuk melakukan pekerjaan dengan baik dan sempurna. Seorang karyawan sebaiknya bekerja dengan segenap kemampuan, keinginan, dan kesungguhan untuk mencapai kesempurnaan dan kesuksesan mereka sendiri, lingkungan sosialnya, dan juga untuk hari akhir. Dalam Islam terdapat konsep ikhsan (keunggulan dan kebajikan) berhubungan dengan kebaikan dan sesuatu yang diperintahkan oleh Allah SWT.

\section{Penilaian Kinerja}

Penilaian kinerja adalah cara pengukuran kontribusi-kontribusi dari individu dalam instansi yang dilakukan terhadap organisasi. ${ }^{22}$ Seorang manajer muslim dalam bertanggungjawab menilai karyawan harus dilakukan secara adil. Menurut Ali dan Junaidah Hasyim sebagaimana yang dikutip oleh Oktania, penilaian kinerja berdasarkan Al-Qur'an evaluasi penilaian terdapat dua metode, yaitu berdasarkan pertimbangan dan berdasarkan

${ }^{21}$ Danang Sunyono, “Manajemen Sumber Daya Manusia”, (Yogyakarta: Caps, 2012), hlm.145.

22 Ambar Teguh S dan Rosidah, "Manajemen....,hlm.223. 
perilaku . ${ }^{23}$ Penilaian yang dilakukan secara periodik akan memberikan banyak manfaat bagi organisasi atau perusahaan karena dapat menentukan hal-hal apa saja yang dapat berjalan baik untuk jangka panjang. Dan bagi individu dapat digunakan sebagai evaluasi diri terhadap pekerjaan untuk mengetahui kesalahan yang terjadi dan mencegah hal itu terulang lagi.

\section{Kendala-Kendala Dalam Implementasi Manajemen Sumber Daya Manusia Berbasis Syariah}

Keragaman tenaga kerja dipengaruhi oleh nilai-nilai budaya dan norma-norma yang berkembang dalam masyarakat. ${ }^{24}$ Beragamnya budaya tenaga kerja akan sangat menentukan ketika mereka bersikap. Sehingga disini diperlukan upaya intensif untuk menyatukan berbagai budaya dengan ikatan bahwa setiap timbul masalah dalam kerja tetap akan mendahulukan kepentingan perusahaan. Keragaman budaya dan sikap ini pun merupakan asset bagi perusahaan, sehingga akan memperoleh hasil yang positif dan kaya dengan imajinasi.

Salah satu kendala yang dihadapi dalam implementasi manajemen sumber daya manusia berbasis syariah adalah sumber daya manusia yang tidak memiliki latar belakang pengetahuan mendalam atau kurang memahami tentang manajemen sumber daya manusia berbasis syariah. Karena dimana lebih banyak perusahaan atau organisasi yang berorientasi pada manajemen sumber daya manusia yang konvensional dari pada syariah. Dan umumnya mereka biasanya hanya diberi training singkat mengenai manajemen sumber daya manusia berbasis syariah lalu baru diterjunkan langsung ke lapangan. Seringkali training seperti ini kurang memadai, karena yang perlu di upgrade bukan hanya knowledge saja tetapi juga visi, misi, serta kepribadian syariah. akibat pendidikan dan training yang singkat, maka tingkat pemahaman hukum syariah pun juga minim.

\section{Solusi Dalam Implementasi Manajemen Sumber Daya Manusia Berbasis Syariah}

Dalam sebuah organisasi atau perusahaan tidak lepas dari adanya kendala atau kesulitan dalam menjalankannya. Seperti halnya dengan wisata edukasi Kampung Coklat Blitar ini yang menghadapi kendala dalam mengimplementasikan manajemen sumber daya manusia berbasis syariah. Dan dalam kendala di suatu organisasi atau perusahaan pasti selalu ada solusi untuk meminimalisir terjadinya hal tersebut. Dalam organisasi atau perusahaan

23 Oktania, "Praktik Manajemen Berbasis Islam pada Perusahaan", Skripsi (Semarang: Fakultas Ekonomi dan Bisnis, UNDIP Semarang, 2012), hlm.63.

${ }^{24}$ Veithzal Rivai, "Manajemen Sumber Daya Manusia untuk Perusahaan Dari Teori ke Praktik”, (Jakarta : PT RajaGrafindo Persada, 2005), hlm.22. 
misalnya pemberlakuan metode reward and punishment yang merupakan hal yang penting untuk membentuk pribadi dari warga organisasi tersebut. Jika punishment akan menghasilkan efek jera, maka reward akan menghasilkan efek sebaliknya yaitu ketauladanan. Imbalan adalah jumlah pembayaran yang diterima dan tingkat kesesuaian antara pembayaran tersebut dengan pekerjaan. (Prof. Dr. FX. Suwarto, M.S.) penghargaan (reward) adalah sebuah bentuk apresiasi kepada suatu prestasi kepada tertentu yang diberikan, baik oleh dan dari perorangan ataupun suatu lembaga yang biasanya diberikan dalam bentuk material atau ucapan. Penghargaan yang diberikan oleh suatu perusahaan atau organisasi kepada karyawan agar mereka bekerja dengan menjadikan modal motivasi yang tinggi dan berprestasi dalam mencapai tujuan-tujuan perusahaan atau organisasi.

Sedangkan hukuman (punishment) adalah sebuah cara untuk mengarahkan dengan tingkah laku yang berlaku secara umum. Dalam hal ini, hukuman diberikan ketika sebuah tingkah laku yang tidak diharapkan ditampilkan oleh orang yang bersangkutan atau orang yang bersangkutan tidak memberikan respon atau tidak menampilkan sebuah tingkah laku yang diharapkan.

\section{METODE PENELITIAN}

Pendekatan yang dilakukan dalam penelitian ini adalah menggunakan metode penelitian kualitatif. Secara sederhana dapat dinyatakan bahwa penelitian kualitatif adalah meneliti subyek penelitian atau informan dalam lingkungan hidup keseharian. Metode penelitian kualitatif juga diartikan sebagai metode penelitian yang berlandaskan pada filsafat postpositivisme, digunakan untuk meneliti pada kondisi obyek yang alamiah, (sebagai lawannya adalah eksperimen) dimana peneliti sebagai instrumen kunci, teknik pengumpulan data dilakukan secara triangulasi (gabungan), analisis data bersifat induktif/kualitatif, dan hasil penelitian kualitatif lebih menekankan makna daripada generalisasi. ${ }^{25}$

Penelitian ini dimasukkan dalam penelitian studi kasus. Yakni, penelitian yang dilakukan secara intensif, terinci, dan mendalam terhadap suatu organisasi, lembaga dan gejala tertentu. Studi kasus adalah strategi yang lebih cocok bila pokok pernyataan suatu penelitian berkenaan dengan "how" atau "why", atau jika peneliti hanya memiliki sedikit peluang yang akan diselikidi. Bilamana untuk mengontrol peristiwa-peristiwa yang akan diselidiki, dan bilamana fokus penelitiannya terletak pada fenomena kontemporer (masa kini) di dalam konteks kehidupan nyata. hlm.13.

25Sugiyono, "Metode Penelitian Kombinasi (Mixed Methods)", (Bandung: Alfabeta, 2016), 
Produk penelitian kasus adalah suatu generalisasi pola-pola kasus yang tipikal dari individu, kelompok, dan sebagainya. Sedangkan, ruang lingkupnya dapat mencakup segmen atau bagian tertentu atau mencakup keseluruhan siklus kehidupan dari individu, kelompok, dan sebagainya, baik dengan penekanan terhadap faktor-faktor kasus tertentu maupun meliputi keseluruhan faktor-faktor dan fenomena-fenomena. ${ }^{26}$ Dalam hal ini yang menjadi pusat perhatian peneliti adalah mengenai implementasi manajemen sumber daya manusia berbasis syariah di kampung coklat Blitar.

\section{HASIL DAN PEMBAHASAN}

\section{Implementasi Manajemen Sumber Daya Manusia Insani di Kampung Coklat Blitar}

Berdasarkan penelitian yang dilakukan di Kampung Coklat Blitar bahwasanya organisasi atau perusahaan ini sudah menerapkan manajemen sumber daya manusia yang berbasis syariah sejak awal berdirinya perusahaan ini yaitu pada tahun 2014. Hal ini dapat diketahui dari syarat-syarat yang diberikan perusahaan untuk karyawan-karyawan baru. Dan perusahaan ini juga selalu memfilter mitra-mitra yang ingin bergabung di perusahaan ini. Hanya mitra yang ownernya beragama Islam saja yang akan diterima.

Pada dasarnya proses rekrutmen yang diterapkan di Kampung Coklat ada dua macam. Yang pertama, yaitu merekrut karyawan tanpa adanya tes-tes tertentu tanpa melihat pendidikannya hal ini dengan merekrut masyarakat sekitar perusahaan. Yang kedua, yaitu proses rekrutmen ini dilaksanakan setelah adanya analisa kebutuhan karyawan baru, hal ini bertujuan agar tidak terjadi kesalahan dalam perekrutan dan penempatannya. Hal ini dibuktikan dengan adanya tes-tes tertentu yang dilakukan oleh pelamar. Oleh karena itu, rekrutmen merupakan langkah awal untuk memperoleh pekerjaan yang berkualitas, yang dapat mendukung perusahaan Kampung Coklat dalam mewujudkan target yang ditentukan. Dalam proses seleksi yang diterapkan di Kampung Coklat Blitar ada dua macam. Yaitu yang pertama, bahwa perusahaan tidak menggunakan proses dan tahapan seleksi dengan menggunakan beberapa tes kepada para pelamar. Namun, perusahaan lebih mementingkan perilaku yang Islami yang dilihat dari kepribadian kandidat. Hal ini berlaku untuk masyarakat sekitar perusahaan yang melamar pekerjaan di perusahaan Kampung Coklat. Yang kedua, perusahaan memang harus selektif dalam penerimaan karyawan dengan menerapkan proses seleksi. hlm.127.

${ }^{26}$ Andi Prastowo, “Memahami Metode-Metode Penelitian”, (Jogjakarta: Ar-Ruzz Media, 2011) 
Seperti halnya yang diterapkan di Kampung Coklat Blitar bahwa dalam menarik karyawan baru hanya akan mengambil calon karyawan yang berkualitas, kompeten, dan yang benar-benar memenuhi kriteria yang telah ditentukan. Artinya, sekalipun calon karyawan tersebut adalah saudara atau teman dari salah satu karyawan yang sudah ada, namun tidak sesuai dengan kriteria maka calon karyawan tersebut tidak dapat menjadi karyawan dengan mengandalkan orang-orang dalam. Karena sistem disini yang digunakan didasarkan pada kualitas dan yang berkompeten saja. Namun hal ini hanya berlaku kepada pelamar selain masyarakat sekitar perusahaan Kampung Coklat.

Sedangkan untuk pelamar dari masyarakat sekitar perusahaan Kampung Coklat tidak ada kriteria-kriteria khusus seperti pelamar yang berasal dari luar. Namun juga harus memenuhi syarat-syarat tertentu, seperti harus beragama Islam, wajib memakai jilbab bagi perempuan, harus jujur, bisa tanggungjawab dengan pekerjaannya. Karena yang dilihat pihak perusahaan dari pelamar masyarakat sekitar yaitu bukan pendidikannya, tetapi semangat bekerjanya.

Pada pelatihan dan pengembangan di perusahaan Kampung Coklat ini setiap satu bulan sekali selalu diadakan pelatihan tiap divisi. Sedangkan pelatihan yang rutin diadakan setiap hari sabtu pagi yang bersifat ibadah, yaitu berupa pengajian. Karena diharapkan karyawan dapat mengamalkan isinya dan menjadi manusia yang lebih baik lagi. Pelatihan yang bersifat ibadah ini selain wajib diikuti oleh semua karyawan, juga diperbolehkan untuk masyarakat sekitar perusahaan yang ingin mengikuti. Pelatihan dan pengembangan ini dilakukan secara rutin tiap bulan dan tiap minggu dalam rangka untuk meningkatkan ketrampilan karyawan, sehingga kualitas produk yang dihasilkan oleh perusahaan juga meningkat.

Pelatihan dan pengembangan itu penting karena keduanya merupakan cara yang digunakan oleh organisasi atau perusahaan untuk mempertahankan, menjaga dan memelihara pegawai publik dalam organisasi sekaligus meningkatkan keahlian para pegawai untuk kemudian dapat meningkatkan produktivitasnya. Dalam program pelatihan, karyawan akan memperoleh banyak keuntungan seperti menambah pengetahuan, pengalaman, bahkan bertemu dengan orang baru. Setelah mengikuti program pelatihan ini, seseorang wajib mengamalkan dan membaginya kepada rekan sejawat agar ilmu yang didapat tidak menjadi sia-sia dan bermanfaat bagi orang lain dan bagi dirinya sendiri. Pengembangan SDM lebih terfokus ke jangka panjang. Melalui program pengembangan akan mengurangi ketergantungan organisasi terhadap adanya program pengangkatan karyawan baru, karena program pengembangan semata-mata untuk memberdayakan karyawan dalam organisasi untuk jangka panjang. 
Islam mendorong untuk melakukan pelatihan terhadap para karyawan dengan tujuan mengembangkan kompetensi dan kemampuan dalam menjalankan tanggungjawab pekerjaannya dan pelatihan ini diutamakan bersifat Islami. Islam menegaskan bahwa pelatihan dan pengembangan mencakup mulai dari pengembangan moral, spiritual, dan pada akhirnya dimuat pada kebijakan fiskal. Pelatihan dan pengembangan harusnya mengantarkan pada peningkatan keimanan kepada Allah SWT dan untuk menambah pengetahuan dan ketrampilan pekerja.

Selain pelatihan dan pengembangan yang bersifat religiuus, perusahaan selalu memberikan motivasi dan dorongan kepada karyawan untuk senantiasa meningkatkan kualitas diri dengan baik. Motivasi tersebut tidak hanya disampaikan oleh pimpinan, supervisor atau staff perusahaan saja, tetapi juga disampaikan kepada pemuka agama yang berasal dari luar perusahaan pada saat ada acara pengajian akbar. Hal ini dilakukan perusahaan Kampung Coklat karena manusia terdiri dari jasmani dan rohani, maka dengan dilaksanakannya hal tersebut karyawan bisa bekerja dengan semangat serta memiliki kepribadian yang baik dan tanggungjawab.

Konsep pelatihan dan pengembangan yang diterapkan oleh perusahaan Kampung Coklat ini tidak hanya mengedepankan potensi dan kualitas karyawan, namun perusahaan juga memberikan pelatihan dan pengembangan berupa moral dan spiritual. Islam menegaskan bahwa pelatihan dan pengembangan harus mencakup semuanya, dimulai dari pengembangan moral dan pengembangan spiritual manusia pada akhirnya dimuat pada peningkatan keimanan kepada Allah SWT untuk menambah pengetahuan dan ketrampilan karyawan sehingga bisa menaikkan level mereka. Islam tidak hanya mendorong manusia untuk bekerja saja, tetapi juga memotivasi untuk melakukan pekerjaan dengan baik dan sempurna.

Untuk penilaian kinerja, pada perusahaan Kampung Coklat ini penilaian dibagi menjadi dua, yaitu penilaian berdasarkan hasil kerja dan penilaian dari perilaku. Penilaian di perusahaan ini dilakukan secara non formal yaitu penilaian langsung dari atasan. Penilaian kinerja menurut perusahaan menekankan pada pada keadilan dan keterbukaan pada saat penilaian. Mengenai tahapan yang dilakukan oleh perusahaan terhadap karyawan yang berprestasi dan bermasalah, untuk karyawan yang berprestasi akan mendapatkan reward dari perusahaan berupa uang. Dan untuk karyawan yang bermasalah yaitu dilakukan pembinaan atau teguran.

\section{Kendala dan Solusi Dalam Implementasi Manajemen Sumber Daya Insani}

Dengan seiring perkembangan zaman semakin banyak perusahaan yang mulai menerapkan manajemen sumber daya manusia yang berbasis syariah, salah satunya wisata 
edukasi Kampung Coklat ini. Namun selama penerapan manajemen sumber daya manusia yang berbasis syariah ini berlangsung sampai sekarang hampir empat tahun, perusahaan Kampung Coklat tidak pernah mengalami kendala dalam penerapan manajemen sumberdaya manusia yang berbasis syariah. Tetapi ada satu kendala yang dihadapi perusahaan, yaitu setiap karyawan harus bersikap ramah dan selalu tersenyum setiap ada wisatawan yang berkunjung. Hal ini agak sulit dilakukan oleh para karyawan jika wisatawan berkunjung pada saat sore hari.

Dalam setiap menjalankan organisasi atau perusahaan pasti tidak lepas dari adanya suatu kendala atau kesulitan. Dan dalam setiap kendala juga ada solusi yang dilakukan untuk meminimalisir terjadinya kendala tersebut. Salah satunya seperti yang dilakukan oleh perusahaan Kampung Coklat Blitar yang mengalami kendala pada sikap karyawan yang mengharuskan selalu tetap ramah dan tersenyum kepada semua pengunjung. Dan solusi untuk meminimalisir adalah diadakannya sistem reward and punishment. Dimana para karyawan akan dilihat dari perilaku dan sikapnya, jika perilaku dan sikapnya baik dengan pengunjung atau karyawan lainnya akan mendapatkan reward sendiri, biasanya berupa uang. Sedangkan karyawan yang berperilaku atau bersikap kurang baik maka akan mendapatkan teguran dari atasan. Hal ini merupakan hal yang penting untuk membentuk pribadi karyawan untuk menjadi lebih baik lagi.

\section{KESIMPULAN}

Berdasarkan pembahasan hasil penelitian yang telah dilakukan terkait dengan analisis implementasi manajemen sumber daya manusia berbasis syariah di Kampung Coklat Blitar, maka dapat ditarik kesimpulan sebagai berikut :

1. Perusahaan Kampung Coklat Blitar sudah menerapkan manajemen sumber daya manusia berbasis syariah, hal ini dibuktikan bahwa setiap kegiatan yang dilakukan di perusahaan harus sesuai dengan ajaran-ajaran Islam. Seperti dalam pelaksanaan penerapan manajemen sumber daya manusia berbasis syariah berikut ini. Yang pertama, dalam sistem rekrutmen yang diterapkan di perusahaan Kampung Coklat Blitar sudah sesuai dengan sistem rekrutmen manajemen sumber daya manusia secara Islami yaitu penarikan tenaga kerja didasarkan pada kemampuan, kecakapan, dan ketrampilan. Sedangkan sistem pelaksanaannya untuk kejujuran dan tanggungjawab sesuai dengan Islam. Kedua, proses seleksi yang diterapkan di perusahaan Kampung Coklat sudah sesuai dengan proses manajemen sumber daya manusia berbasis syariah yaitu pelamar harus memenuhi syarat-syarat seperti beragama Islam, jujur, dapat dipercaya, tanggungjawab. Selain itu juga didasarkan pada kemampuan, kecakapan 
dan ketrampilan. Ketiga, pelatihan dan pengembangan sudah sesuai dengan teori manajemen sumber daya manusia berbasis syariah yaitu pelatihan dan pengembangan yang diberikan perusahaan tidak hanya berupa moral dan spiritual saja tapi juga yang bersifat religious. Sehingga dapat meningkatkan keimanan kepada Allah SWT dan menambah pengetahuan dan ketrampilan karyawan sehingga memotivasi karyawan untuk melakukan pekerjaan dengan baik. Keempat, penilaian kinerja dilakukan secara periodik dengan adil dan terbuka. Hal ini dapat memberikan manfaat pada jangka panjang dan sistem penilaian kinerja di perusahaan cukup maksimal dengan adanya pemberian reward terhadap karyawan yang bekerja keras dan berperilaku baik. Nantinya pemberian reward ini akan memotivasi karyawan lainnya untuk dapat meningkatkan kinerjanya.

2. Dalam implementasi manajemen sumber daya manusia berbasis syariah perusahaan Kampung Coklat tidak mengalami kendala Selma penerapan tersebut. Namun, ada satu kesulitan yang dialami perusahaan Kampung Coklat ini yaitu setiap karyawan harus bersikap selalu tersenyum setiap ada wisatawan yang berkunjung. Hal ini agak sulit dilakukan oleh para karyawan jika wisatawan berkunjung pada saat sore hari.

3. Untuk meminimalisir adanya kendala yang terjadi perusahaan Kampung Coklat Blitar menggunakan sistem reward and punishment dimana setiap karyawan yang mempunyai perilaku dan sikap baik akan mendapatkan reward. Sebaliknya karyawan yang berperilaku kurang baik akan mendapatkan punishment berupa teguran.

\section{DAFTAR PUSTAKA}

Alma, Buchari dan Donni Juni Priansa. 2014. Manajemen Syariah. Bandung: Alfabeta.

Arifin, Zainul. 2005. Dasar-Dasar Manajemen Bank Syariah. Jakarta: Alvabeta.

Aziziyah, Mei Sulastri Sonya. 2014. Praktik Penerapan Manajemen Sumber Daya Manusia Berbasis Islam pada Steak and Shake di Perusahaan Waroeng Group Timoho Yogyakarta. Skripsi. Yogyakarta: Fakultas Ekonomi, UIN Syarif Hidayatullah Yogyakarta.

Damingun. Peran Pelatihan Sumber Daya Manusia Dalam Perspektif Islam. Jurnal STIE Muhammadiyah Samarinda, Vol.10 No.1 Tahun 2016.

Depdiknas. 2008. Kamus Bahasa Indonesia. Jakarta: Pusat Bahasa.

Fathoni, Abdurrahmat. 2006. Organisasi dan Manajemen Sumber Daya Manusia. Jakarta: PT. Rineka Cipta.

Gomes, Faustino Cordoso. 2003. Manajemen Sumber Daya Manusia. Yogyakarta: Andi Offset.

Hasibun, Malayu. 2009. Manajemen Sumber Daya Manusia Edisi Revisi. Jakarta: Bumi Aksara. 
Hasim, Jumaidah. Penerapan Manajemen Islam dalam Suatu Organisasi (Studi di Internasional Islamic University Malaysia). Vol.2 No.3. 2009.

Martyo, Susilo. 1990. Manajemen Sumber Daya Manusia. Yogyakarta: BPFE-Yogyakarta.

Mulyasa, E. 2004. Manajemen Berbasis Sekolah. Bandung: PT. Remaja Rosdakarya.

Mustaqim, Muhammad. Prinsip Syariah Dalam Manajemen Sumber Daya Manusia (studi atas implementasi manajemen sumber daya manusia UMKM di Kudus). Jurnal STAIN Kudus, Vol.10 No.2 Tahun 2016.

Oktania. 2012. Praktik Manajemen Berbasis Islam pada Perusahaan. Skripsi. Semarang: Fakultas Ekonomi dan Bisnis, UNDIP Semarang.

Prastowo, Andi. 2011. Memahami Metode-Metode Penelitian. Jogjakarta: Ar-Ruzz Media.

Rahmatika, Fadhilah. 2014. Penerapan MSDM Berbasis Nilai-Nilai Islami pada Bank BNI Syariah Semarang. Skripsi. Semarang: Fakultas Ekonomika dan Bisnis, UNDIP Semarang.

Rivai, Veithzal. 2005. Manajemen Sumber Daya Manusia untuk Perusahaan Dari Teori ke Praktik. Jakarta : PT RajaGrafindo Persada.

Rivai, Veithzal dan Ella Jauvani S. 2009. Manajemen Sumber Daya Manusia untuk Perusahaan (Teori dan Praktik), Edisi kedua. Jakarta: Rajawali Pers.

Sugiyono. 2016. Metode Penelitian Kombinasi (Mixed Methods). Bandung: Alfabeta.

Sunyono, Danang. 2012. Manajemen Sumber Daya Manusia. Yogyakarta: Caps.

Teguh, S Ambar dan Rosidah. 2003. Manajemen Sumber Daya Manusia (Konsep, Teori dan Pengembangan dalam Konteks Organisasi Publik. Yogyakarta: Graha Ilmu.

Yusanto, Muhammad Islamil dan Muhammad Karebeet W. 2012. Menggagas Bisnis Islam. Jakarta : Gema Insani Press.

Yusuf, Burhanuddin. 2015. Manajemen Sumber Daya Manusia di Lembaga Keuangan Syariah. Jakarta: PT. RajaGrafindo Persada. 